\title{
PENERAPAN METAKOGNETIF SEBAGAI STRATEGI PEMBELAJARAN MANDIRI SISWA DALAM PEMBELAJARAN BAHASA ARAB
}

\author{
Aliyah \\ Institut Agama Islam Negeri Palangka Raya \\ aliyah.@yahoo.com
}

\begin{abstract}
Abstrac: Metacognitive is a word that relates to what is known about him as an individual who learns and how he controls and adjusts his behavior. Someone needs to be aware of the shortcomings and advantages they have. Metacognitive is a form of ability to look at yourself so that what he does can be optimally controlled. To find out the metacognitive students, the teacher must train them to 1) design what they want to learn, 2) monitor the progress of student learning, 3) assess what has been learned. By knowing the cognition of each student, self-learning can be carried out independently, with independent learning the complex components of Arabic will be studied maximally.
\end{abstract}

Keywords: Metacognitive, Independent Learning. Arabic learning

\begin{abstract}
Abstrak: Metakognitif adalah kata yang berhubungan dengan apa yang diketahui tentang dirinya sebagai individu yang belajar dan bagaimana dia mengendalikan dan menyesuaikan perilakunya. Seseorang perlu menyadari keurangan dan kelebihan yang merea miliki. Metaognitif adalah bentuk kemampuan untuk melihat diri sendiri sehingga apa yang dilakukannya dapat diendalikan secara optimal. Untuk mengetahui siswa metakognitif, guru harus melatih mereka untuk 1) merancang apa yang ingin mereka pelajari, 2) memantau emajuan belajar siswa, 3) menilai apa yang telah dipelajari. Dengan mengetahui kondisi masing-masing siswa, belajar mandiri dapat dilakukan secara bebas, dengan belajar mandiri, komponenkomponen kompleks bahasa Arab akan dipelajari secara maksimal.
\end{abstract}

Kata kunci: Metakognitif, pembelajaran mandiri, pembelajaran bahasa Arab.

\section{Pendahuluan}

Mata pelajaran bahasa arab merupakan suatu mata pelajaran yang diarahkan untuk mendorong, membimbing, mengembangkan dan membina kemampuan serta menumbuhkan sikap positif terhadap bahasa arab baik Reseptif maupun Produktif. Kemampuan Resertif yaitu kemampuan untuk memahami pembicaraan orang lain dan memahami bacaan. Kemampuan Produktif yaitu kemampuan menggunakan bahasa sebagai alat komunikasi baik secara lisan maupun tulis. Kemampuan berbahasa arab serta sikap positif terhadap bahasa arab tersebut sangat penting dalam membantu memahami sumber ajaran islam 
yaitu Al-Qur'an dan Hadits, serta kitab-kitab bahasa arab yang berkenaan dengan islam bagi peserta didik.

Imam Syafi'i telah memberikan penjelasan tentang pentingnya bahasa Arab. Dengan membedakan kebutuhan setiap orang muslim akan bahasa Arab, dan kebutuhan bagi yang ingin memiliki ilmu guna memahami al-Qur'an dan Sunnah serta memahami hukum-hukum yang ada di dalamnya. ${ }^{1}$

Di dalam bahasa arab ada yang namanya unsur bahasa dan keterampilan bahasa. Unsur bahasa terdiri dari, bunyi (aswat), tata bahasa (qawaid), dan kosakata (mufrodat), sedangkan keterampilan bahasa terdiri dari empat keterampilan, yaitu keterampilan mendengar (Maharat al-Istima'), keterampilan berbicara (Maharat al-Kalam), keterampilan membaca (Maharat al-Qira'at), dan keterampilan menulis (Maharat al-Kitabah). Keempat aspek ini menjadi aspek penting dalam belajar bahasa Arab, karena keempat keterampilan tersebut tidak dapat dipisahkan. Karena kedudukan keempat keterampilan ini sangat menunjang dalam pencapaian keterampilan berbahasa. ${ }^{2}$

Pembelajaran bahasa arab di Indonesia dengan bertujuan memahami sumber ajaran Islam maka pembelajaran bahasa arab haruslah mendapatkan perhatian khusus, bukan dari segi materi saja bahkan hal yang terpenting ialah masalah waktu, di Indonesia pembelajaran bahasa arab mendapatkan porsi waktu yang sedikit di Madrasah Ibtidayah bahasa arab hanya mendapatkan waktu 2 jam sedangkan di Madrasah Tsanawiyah mendapat waktu 3 jam dan Madrasah Aliyah untuk kelas X mendapat waktu 4 jam dan 2 jam untuk kelas XI dan XII di setiap minggunya.

Dengan sedikitnya waktu pembelajaran maka guru harus bisa mengatur pembelajaran agar tujuan bisa tercapai salah satunya dengan menggunakan strategi pembelajaran yang efektif diantara strategi yang bisa digunakan guru adalah metakognitif strategi ini bertujuan untuk mengetahui kesadaran seseorang tentang bagaimana ia belajar, kemampuan untuk menilai kesukaran sesuatu masalah, kemampuan untuk mengamati tingkat pemahaman dirinya, kemampuan menggunakan berbagai informasi untuk mencapai tujuan, dan kemampuan menilai kemajuan belajar sendiri.

\footnotetext{
${ }^{1}$ Muhammad Idris al-Syâfi'i, al-Risâlah, (Mustafâ al-Bâby al-Halaby, 1940), hlm. 84

${ }^{2}$ Taufik, Pembelajaran Bahasa Arab MI (Metode Aplikatif \& Inofatif Berbasis ICT), (Surabaya : PMN, 2011), hlm. 43
} 
Dengan mengetahui kemampuan kognitif diri sendiri maka siswa dapat menentukan strategi pembelajaran yang sesuai dengan apa yang di butuhkannya. Sehingga terciptalah pembelajaran mandiri, untuk dapat memenuhi target dan tujuan yang ingin dicapai.

\section{Pengertian Metakognitif}

Metakognitif merupakan suatu kemampuan di mana individu berdiri di luar kepalanya dan mencoba untuk memahami cara ia berfikir atau memahami proses kognitif yang dilakukannya dengan melibatkan komponen-komponen perencanaan (functional planning), pengontrolan (self-monitoring), dan evaluasi (self-evaluation). ${ }^{3}$

Flavel memberikan definisi metakognitif sebagai kesadaran seseorang tentang bagaimana ia belajar, kemampuan untuk menilai kesukaran sesuatu masalah, kemampuan untuk mengamati tingkat pemahaman dirinya, kemampuan menggunakan berbagai informasi untuk mencapai tujuan, dan kemampuan menilai kemajuan belajar sendiri. Sementara menurut Margaret W. Matlin dalam Desmita4 mengungkapkan metakognitif adalah "knowledge and awareness about cognitive processes - or our thought about thinking".

Pengertian metakognisi yang dikemukakan oleh para pakar di atas sangat beragam, namun pada hakekatnya memberikan penekanan metakognisi adalah suatu kesadaran peserta didik dalam menggunakan pemikiranya untuk merencanakan, mempertimbangkan, mengontrol dan menilai terhadap proses serta strategi kognitif milik dirinya dalam menghadapi masalah. Metakognisi ini memiliki arti yang sangat penting, karena pengetahuan tentang proses kognisi sendiri dapat memandu kita dalam menata suasana dan menyeleksi strategi untuk meningkatkan kemampuan kognitif kita dimasa yang akan datang.

Jadi metakognitif adalah suatu kesadaran tentang kognitif kita sendiri, bagaimana kognitif kita bekerja serta bagaimana mengaturnya. Kemampuan ini sangat penting terutama untuk keperluan efisiensi penggunaan kognitif kita dalam

\footnotetext{
${ }^{3}$ Desmita, Psikologi Perkembangan Peserta Didik, (Bandung: PT. Remaja Rosda Karya, 2010), hlm. 133. ${ }^{4}$ Desmita, Psikologi Perkembangan Peserta Didik, hlm. 137.
} 
menyelesaikan masalah. Secara ringkas metakognitif dapat diistilahkan sebagai "thinking about thingking".

Intinya, metakognitif adalah kesadaran berfikir tentang apa yang diketahui dan apa yang tidak diketahui. Dalam konteks pembelajaran, peserta didik mengetahui kemampuan dan modalitas belajar yang dimiliki, dan mengetahui strategi belajar yang terbaik untuk belajar efektif.

\section{Komponen Metakognitif}

Adapun Komponen Metakognitif menurut Brown secara khusus membatasi empat komponen dari metakognitif yaitu: perencanaan, pemantauan, pengevaluasian, dan perevisian. Keempat komponen ini dapat dijelaskan sebagai berikut: 1) Perencanaan berkaitan dengan aktivitas yang disengaja yang mengorganisir seluruh proses belajar. 2) Pemantauan berkaitan dengan aktivitas mengarahkan rangkaian kemajuan belajar. 3) Pengevaluasian berkaitan dengan mengevaluasi proses belajar diri sendiri meliputi pengukuran kemajuan yang dicapai pada kreativitas belajar. 4) Perevisian proses belajar diri sendiri meliputi modifikasi rencana sebelumnya dengan memperhatikan tujuan, strategi dan pendekatan belajar lainnya. ${ }^{5}$

Sedangkan Cohors-Fresenborg dan Kaune merangkum komponenkomponen metakognitif ke dalam 3 aktivitas metakognisi yang dilakukan pada pemecahan masalah yang terdiri dari:

\section{Proses merencanakan}

Pada proses ini diperlukan peserta didik untuk meramal apakah yang akan dipelajari, bagaimana masalah itu dikuasai dan kesan dari pada masalah yang dipelajari, dan merencanakan cara tepat untuk memecahkan suatu masalah.

\section{Proses memantau}

Pada proses ini peserta didik perlu mengajukan pertanyaan pada diri sendiri seperti apa yang saya lakukan? apa makna dari soal ini?, bagaimana saya harus memecahkannya?, dan mengapa saya tidak memahami soal ini?.

\section{Proses menilai/evaluasi}

${ }^{5}$ M. Lee dan Baylor AL, "Designing Metacognitive maps for Web-Based Learning, educational Technology \& society”, Volume 9 Nomor 1, hlm. 344-348 
Pada proses ini peserta didik membuat refleksi untuk mengetahui bagaimana suatu kemahiran, nilai dan suatu pengetahuan yang dikuasai oleh peserta didik tersebut. Mengapa peserta didik tersebut mudah atau sulit untuk menguasainya, dan apa tindakan atau perbaikan yang harus dilakukan. ${ }^{6}$

Adapun upaya-upaya yang harus dilakukan guru dalam mengembangkan kemampuan metakognitif dan strategi kognitif peserta didik antara lain: 1) Guru harus mengajarkan dan menganjurkan kepada peserta didik untuk menggunakan strategi belajar yang sesuai dengan kelompok usia mereka. 2) Memberikan pelatihan tentang strategi belajar, kapan dan bagaimana menggunakan strategi untuk mempelajari tugas-tugas baru dan sulit. 3) Menunjukkan strategi belajar yang efektif serta mendorong peserta didik untuk menggunakan strateginya sendiri. 4) Mengidentifikasi situasi-situasi di mana suatu strategi memungkinkan untuk digunakan. 5) Memberi kesempatan kepada peserta didik untuk belajar sendiri, dengan sedikit atau tanpa bantuan dari guru. 6) Memberi kesempatan seluas-luasnya kepada peserta didik untuk mengakses hasil belajarnya sendiri, sehingga mereka bisa mengetahui apa yang telah dikerjakannya dan apa yang belum diketahuinya. 7) Sering memberikan umpan balik tentang kemajuan belajar mereka. 8) Memberi kesempatan kepada siswa untuk mengevaluasi belajarnya sendiri dan menolong mereka mengembangkan mekanisme melakukan perbuatan belajar yang efektif. 9) Mengharapkan dan menganjurkan peserta didik untuk belajar mandiri, yakni melakukan perbuatan belajar sendiri, menentukan sendiri apa yang harus dilakukan, memecahkan masalah sendiri, tanpa bergantung kepada orang lain. ${ }^{7}$

\section{Prosedur Matakognitif}

Berikut ini prosedur sistem kerja strategi metakognitif: pertama; Memusatkan belajar yang meliputi: 1) Mengulas materi baru dan menghubungkan dengan materi yang sudah dikuasai. 2) Memberi perhatian terhadap pokok bahasan. 3) Menunda percakapan atau obrolan dengan orang lain untuk memusatkan pikiran terfokus pada pokok bahasan.

\footnotetext{
${ }^{6}$ Cohors-Frosenborg dan Kaune, "Modelling Classroom Discussion and Categirizing Discursive and Metacognitive Activities", In proceeding of CERME 5, hlm. 1180-1189

${ }^{7}$ Desmita, Psikologi Perkembangan Peserta Didik, hlm. 143-144.
} 
Kedua; Mengatur dan merencanakan belajar yang meliputi: 1) Mencari tahu tentang pembelajaran bahasa, 2) Mengatur, 3) Menentukan tujuan, mengidentifikasi tujuan pembelajaran bahasa (tujuan mendengar/ membaca/ menulis/ berbicara), 4) Merencanakan untuk tugas bahasa, 5) Mencari kesempatan latihan.

Ketiga; Mengevaluasi belajar yang meliputi: 1) Memonitor atau mengewasi diri, 2) Mengevaluasi diri terhadap porses dan hasil belajar.

\section{Pengertian Belajar Mandiri}

Menurut Slameto, "belajar adalah suatu proses perubahan yaitu perubahan tingkah laku sebagai hasil dari interaksi dengan lingkungannya dalam memenuhi kebutuhan hidupnya". ${ }^{8}$

Sedangkan secara terminologi, banyak tokoh yang telah mendefinisikan belajar, di antaranya adalah sebagai berikut: proses usaha yang dilakukan seseorang untuk memperoleh suatu perubahan tingkah laku yang baru secara keseluruhan yang ditampakkan dalam peningkatan kecakapan pengetahuan, sikap, tingkah laku, pemahaman, keterampilan, daya pikir, dan kemampuan lain, sebagai hasil pengalamannya sendiri dalam interaksi dengan lingkungannya.

Belajar mandiri merupakan kegiatan belajar aktif yang didorong oleh niat atau motif untuk menguasai suatu kompetensi guna untuk menyelesaikan suatu masalah, hal tersebut dibangun dengan bekal pengetahuan atau kompetensi yang telah dimiliki. Penetapankompetensi sebagai tujuan belajar, dan cara pencapaiannya baik penetapan waktu belajar, tempat belajar, sumber belajar maupun evaluasi hasil belajar dilakukan oleh pembelajaran mandiri.

Menurut Knowless (1975), belajar mandiri adalah suatu proses dimana individu mengambil inisiatif dengan atau tanpa bantuan dari orang lain untuk mendiagnosa kebutuhan belajarnya sendiri, merumuskan atau menentukan tujuan belajarnya sendiri, mengidentifikasi sumber-sumber belajar, memilih dan melaksanakan strategi belajarnya, serta mengevaluasi hasil belajarnya sendiri.

\footnotetext{
${ }^{8}$ Slameto, Belajar dan Faktor yang Mempengaruhinya, (Jakarta: Rineka Cipta, 2010), hlm. 2.
} 
Sedangkan menurut Haris Mujiman, belajar mandiri adalah kegiatan belajar yang diawali dengan kesadaran adanya masalah, disusul dengan timbulnya niat melakukan kegiatan belajar secara sengaja untuk menguasai sesuatu kompetensi yang diperlukan guna mengatasi masalah. ${ }^{9}$

Dari pendapat beberapa ahli diatas, dapat disimpulkan bahwa belajar mandiri adalah kegiatan belajar aktif, yang didorong oleh niat atau motif untuk menguasai sesuatu kompetensi guna mengatasi sesuatu masalah, dan dibangun dengan betul pengetahuan atau kompetensi yang telah dimiliki, belajar mandiri sebagai strategi yang dapat didefinisikan sebagai suatu pembelajar yang memposisikan pembelajar sebagai penanggung jawab, pemegang kendali, pengambil keputusan atau inisiatif dalam memenuhi dan mencapai keberhasilan belajarnya sendiri dengan atau tanpa bantuan dari orang lain.

\section{Langkah-Langkah Pelaksanaan Belajar Mandiri}

Sedangkan dalam proses belajar mandiri ini ada beberapa langkahlangkah yang akan dilakukan oleh pembelajar baik satu orang atau kelompok yaitu $: 10$

\section{Menetapkan tujuan}

Pembelajar memilih atau berpartisipasi dalam memilih, untuk bekerja demi sebuah tujuan penting, baik yang tampak maupun yang tidak tampak, yang bermakna bagi dirinya maupun orang lain.

Tujuan bukanlah akhir dan semuanya. Tujuan itu akan memberikan kesempatan untuk menerapkan keahlian profesional akademik kedalam kehidupan sehari-hari. Saat pembelajar mencapai tujuan yang berarti dalam kehidupan sehari-hari, proses tersebut membantu mereka mencapai standar akademik yang tinggi.

\section{Membuat rencana}

Pembelajar menetapkan langkah-langkah untuk mencapai tujuan mereka. Merencanakan disini meliputi melihat lebih jauh ke depan dan memutuskan bagaimana cara untujk berhasil. Rencana yang diputuskan siswa tergantung pada

\footnotetext{
${ }^{9}$ Haris Mudjiman, Belajar Mandiri, (Surakarta : UNS Press, 2008), hlm, 1

${ }^{10}$ Elaine B. Johnson, Contextual Teaching and Learning : Menjadikan Kegiatan Belajar Mengajar Mengasyikkan dan Bermakna, (Bandung : Mizan Learning Center, 2007), hlm, 172-175
} 
apakah mereka ingin menyelesaikan masalah, menentukan persoalan, atau menciptakan suatu proyek.

Rencana yang dibuat seseorang bergantung pada tujuannya. Baik tujuan tersebut melibatkan penyelesaian masalah, menyelesaikan persoalan tersebut, semuannya membutuhkan pengambilan tindakan, mengajukan pertanyaan, membuat pilihan, mengumpulkan dan menganalisa informasi, serta berfikir secara kritis, dan kritis. Kemampuan untuk melakukan hal-hal tersebut memungkinkan keberhasilan pembelajaran mandiri.

\section{Mengikuti rencana dan mengukur kemajuan diri}

Dari semula, pembelajar tidak hanya menyadari tujuan mereka, tetapi mereka juga harus menyadari keahlian akademik mereka yang harus dikembangkan serta kecakapan yang diperoleh dalam proses belajar mandiri. Selain proses tersebut mereka harus mengevaluasi seberapa baik rencana mereka berjalan.

\section{Membuahkan hasil akhir}

Pembelajar mendapatkan suatu hasil baik yang tampak maupun yang tidak tampak bagi mereka. Ada ribuan cara untuk menampilkan hasil-hasil dari pembelajaran mandiri. Yang paling jelas adalah sebuah kelompok mungkin menghasilkan portofolio, dan dapat pula memberikan informasi menggunakan grafik, tampil untuk mempresentasikan hasil belajar mereka dan siap dikomentari oleh pembelajar yang lainnya.

\section{Menunjukkan kecakapan melalui penilaian autentik.}

Para pembelajar menunjukkan kecakapan terutama dalam tugas-tugas yang mandiri dan autentik. Dengan menggunakan standart nilai dan penunjuk penilaian untuk menilai portofolio, jurnal, presentasi, dan penampilan pembelajar sehingga pengajar dapat memperkirakan tingkat pencapaian akademik mereka. Sebagai tambahan penilaian autentik menunjukkan sedalam apakah proses belajar mengajar yang diperoleh siswa dari pembelajaran mandiri tersebut. Proses belajar mandiri adalah proses yang kaya, bervariasi, dan menantang. Keefektifan bergantung tidak hanya pada pengetahuan dan dedikasi pembelajar, tetapi juga dedikasi dan keahlian pengajar.

Sedangkan ciri khusus program belajar mandiri yang bermutu meliputi halhal berikut : 1) Kegiatan belajar untuk siswa dikembangkan dengan cermat dan 
rinci. Pengajaran sendiri berlangsung dengan baik apabila bahan disusun menjadi langkah-langkah yang terpisah dan kecil, masing-maing membahas satu konsep tunggal atau sebagian dari bahan yang diajarkan. 2) Kegiatan dan sumber pengajaran dipilih dengan hati-hati dengan memperhatikan sasaran pengajaran yang dipersyaratkan. 3) Penguasaan pembelajar terhadap setiap langkah harus diperiksa sebelum ia melanjutkan ke langkah berikutnya. 4) Apabila muncul kesulitan, pembelajar mungkin perlu mempelajari lagi atau meminta bantuan pengajar. Jadi, pembelajar secara terus-menerus ditantang, harus menyelesaikan kegiatan yang diikutinya, langsung mengetahui hasil belajar atau usahanya, dan merasakan keberhasilan. ${ }^{11}$

Sedangkan peran guru dalam belajar mandiri adalah: 1) Pengajar sebagai Demostrator. Dalam perananya sebagai demonstrator hendaknya pengajar senantiasa mengembangkan dalam artian meningkatkan kemampuannya dalam hal ilmu yang dimilikinya karena hal ini sangat menentukan hasil belajar yang dicapai oleh siswa. ${ }^{12}$ 2) Pengajar sebagai Organisator. Guru sebagai organisator, pengelola akademik, silabus, jadwal pelajaran, dll. Komponen yang berkaitan dengan kegiatan belajar mengajar, semua diorganisasikan dengan sedemikian rupa, sehingga dapat mencapai efektivitas, dan efisien belajar pada diri pembelajar. $^{13}$ 3) Pengajar sebagai Motivator. Peranan pengajar sebagai motivator ini penting artinya dalam rangka meningkatkan kegairahan dan pengembangan kegiatan belajar. 4) Pengajar sebagai Pengarah. Dalam hal ini, pengajar harus dapat membimbing dan mengarahkan kegiatan belajar pembelajar sesuai dengan tujuan yang dicita-citakan. 5) Pengajar sebagai Transmitter. Dalam kegiatan mengajar pengajar juga akan bertindak selaku penyebar kebijaksanaan pendidikan dan pengetahuan.

\section{Pembelajaran Bahasa Arab}

\section{Unsur Bahasa Arab}

\section{Bunyi (Aswat).}

\footnotetext{
${ }^{11}$ Jerold E Kemp, Proses Perancangan Pengajaran, (Bandung : ITB, 1994), hlm, 155.

${ }^{12}$ Moh. Uzer Usman, Menjadi Guru Profesional, (Bandung: Remaja Rosdakarya, 2006), hlm, 9.

${ }^{13}$ Sardiman, Interaksi dan Motivasi Belajar Mandiri, (Jakarta: Rajawali,1990), hlm, 142.
} 
Bunyi adalah bekas dari ucapan getaran suara dari suatu objek dan dipindahkan kedalam pusat materi yang sadar dengan rasa suara. Bunyi sendiri dijelaskan oleh kalimat yang mana kalimat adalah bagian dari jumlah sebagai bagan untuk berkomunikasi. Oleh karena itu, suara merupakan dasar bangunan dalam susunan kalimat. Dan mempelajari suara yang pertama kali tentunya yang berkaitan dengan bahasa dan memperhatikanya dengan lebih. ${ }^{14}$ Tentunya dengan bantuan ilmu Ashwat (Ilmu Bunyi/Fonologi) dapat diketahui sedikit banyak kajian pembahasan tentang bunyi.

Langkah pembelajaran Aswat. Dalam hal ini ada tiga cara yang lazim dugunakan, yaitu cara sintesis (merangkai), cara analitis (mengupas), dan gabungan dari dua cara tersebut, yaitu analitis-sintesis. Yang pertama berangkat dari bagian-bagian (suku kata dalam bahasa Indonesia atau bunyi huruf bersyakal dalam bahasa arab) menuju keutuhan (kata), sedangkan yang kedua berangkat dari keutuhan (kata) menuju bagian-bagian.

\section{Cara Sintesis (Tarkibiyah).}

Hal ini dimulai dengan mengenalkan bunyi huruf-huruf, kemudian dirangkai menjadi kata. Contoh:

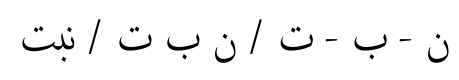

\section{Cara Analitis (Tahliliyah).}

Hal ini dimulai dengan kata, kemudian dikupas menjadi bunyi huruf-huruf, atau dimulai dengan kalimat, kemudian dikupas menjadi kata-kata, dan dikupas lagi menjadi huruf-huruf. Contoh:

$$
\text { ن - ب - ت / ن ب ت / نبت }
$$

\section{Analitis-sintesis (Tahliliyah-Tarkibiyah).}

Hal ini merupakan penggabungan kedua metode. ${ }^{15}$ Analitis ini biasanya dimulai dengan penyajian kata yang telah dikenal oleh siswa, atau untuk bahasa asing dengan bantuan gambar.

\footnotetext{
${ }^{14}$ Abdul Wahab Rasyidi., Ilmu al-Ashwat an-Nuthqi. (Malang: UIN Malang Press), hlm. 1

${ }^{15}$ Ahmad Fuad Effendy, Metodologi Pengajaran Bahasa Arab, (Malang: Misykat, 2012), hlm. 110
} 


\section{Kosakata (Mufrodat).}

Kosakata (mufrada't) jamak dari mufrad yang dalam bahasa Inggrisnya Vocable atau sering disebut dengan vocabulary, artinya himpunan kata atau khazanah kata yang diketahui oleh seseorang atau kelompok, atau merupakan bagian dari suatu bahasa tertentu. Ada juga yang mengartikan sebagai kumpulan kosakata yang digunakan oleh seseorang baik lisan maupun tulisan yang sudah memiliki pengertian dan uraian terjemahannya tanpa dirangkaikan dengan katakata lain serta tersusun secara abjadiyah. ${ }^{16}$

Langkah pembelajaran mufrodat:

\section{Mendengarkan kata}

Ini adalah tahap yang pertama. Berikan kesempatan kepada siswa untuk mendengarkan kata yang diucapkan guru. Baik bendiri sendiri maupun didalam kalimat.apabila unsur bunyi dari kata itu sudah di kuasai oleh siswa, maka dalam dua atau tiga kali pengulangan, siswa telah mampu mendengarkan secara benar.

\section{Mengucapkan kata}

Tahap berikutnya adalah memberi kesempatan kepada siswa untuk mengucapkan kata yang telah didengarnya. Mengucapkan kata baru membantu siswa mengingatnya dalam waktu yang lebih lama.

\section{Mendapatkan makna kata}

Berikan arti kata kepada siswa dengan sedapat mungki menghindari terjemahan, kecuali kalau tidak ada jalan lain. Saran ini dikemukakan, karena kalau guru setiap kali selalu menggunakan bahasa ibu siswa, maka tidak akan terjadi komunikasi langsung dalam bahasa yang sedang dipelajari, sementara itu makna kata akan cepat dilupakan oleh siswa.

\section{Membaca kata}

Setelah siswa mendengar, mengucapkan dan memahami makna kata-kata baru, guru menulisnya dipapan tulis. Setelah siswa diberi kesmpatan untuk membacanya dengan suara keras. Disini untuk kesekian kalinya guru perlu mengecek keakuratan bacaan siswa, agar tidak terjadi kesalahan pengucapan.

\section{Menulis kata}

Akan sangat membantu penguasaan kosa kata, kalau siswa diminta menulis kata-kata yang baru dipelajarinya pada saat makna kata-kata itu masih segar

\footnotetext{
${ }^{16}$ Zulhannan, Teknik Pembelajaran Bahasa Arab Interaktif, (Jakarta: Rajawali Press, 2014), hlm. 109
} 
dalam ingatan siswa. Siswa menulis di bukunya masing-masing dengan mencontoh apa yang ditulis guru dipapan tulis.

\section{Membuat kalimat}

Tahap terakhir dari kegiatan pengajaran pengajaran kosa kataadalah dengan menggunakan kata-kata baru itu dalam sebuah kalimat yang sempurna, secara lisab maupn tertulis. Guru memberikan cotoh kalimat kemudian meminta siswa membuat kalimat serupa. Latihan seperti ini sangat membantu memantapkan pengertian siswa terhadap makna kata. ${ }^{17}$

\section{Tata bahasa (Qawaid)}

Qawaid merupakan jama dari kata qaidah yang berarti aturan, undangundang. ${ }^{18}$ Qawaid adalah aturan-aturan atau kaidah-kaidah yang terdapat dalam menyusun kalimat bahasa Arab, di mana cabang dari ilmu qawaid ini sangat banyak diantaranya adalah ilmu nahwu dan sharaf. Nahwu adalah ilmu tentang pokok-pokok yang dengannya dapat diketahui hal-ihwal, kata-kata bahasa arab dari segi i'rob dan bina'nya, yaitu dari sisi yang dihadapinya dalam keadaan katakata itu disusun. Didalamnya diketahui apa yang wajib terjadi dari harakat akhir dari suatu kata, dari rofa', nasab, jar, atau jazem, atau tetap saja pada suatu keadaan setelah kata tersebut tersusun didalam suatu kalimat. ${ }^{19}$

Langkah pembelajaran qawaid:

\section{Melakukan Pendahuluan.}

Dalam fase ini guru bertanya jawab dengan siswa tentang pelajaran yang telah lalu yang berhubungan dengan pelajaran baru. Dengan kata lain pengetahuan yang telah dimiliki siswa di jadikan dasar untuk pelajaran selanjutnya yang belum mereka kuasai.

\section{Memperlihatkan contoh-contoh.}

Contoh yang diambilkan dari al-Qur'an atau al-Hadits atau ungkapan sederhana itu ditulis di papan tulis, lalu guru menyuruh membaca dan memahaminya, hendaklah diberi garis bawah pada kata-kata yang perlu diberi harakat secukupnya.

\section{Memperbandingkan}

\footnotetext{
${ }^{17}$ Ahmad Fuad Efendy, hlm. 132-133

${ }^{18}$ Ahmad Warson Munawwir, Al-Munawwir Kamus Bahasa Arab-Indonesia, (Surabaya: Pustaka Progresif, 1997), hlm. 1138

${ }^{19}$ Syekh Mustafa Ai-Ghulayaini, Tarjamah Jami'ud Durusil Arabiyyah,(Semarang: CV Asy-Syifa, 1991), hlm. 15
} 
Guru bertanya jawab dengan siswa tentang contoh-contoh tersebut. Satu demi satu, mana saja yang berbeda dan mana yang ada persamaannya apa jenis katanya dan apa macam i'robnya, dan sebagainya. Dengan demikian guru bersama siswa dapat mengambil kesimpulan bersama dari kaidah tersebut.

\section{Mengambil kesimpulan.}

Setelah selesai memperbandingkan dan mengetahui sifat-sifat yang ada persamaannya atau perbedaannya dalam misal itu, maka dapatlah guru bersama siswa mengambil kesimpulan kaidah tadi dengan memberikan nama istilahnya. Kemudian guru menuliskan kaidah itu di papan tulis dan menyuruh salah seorang murid membacanya.

\section{Melakukan Tatbiq.}

Setelah siswa mengetahui pokok kaidah, haruslah siswa tersebut diberi latihan sesuai dengan kaidah tersebut. Melalui langkah-langkah sebagai berikut: 1) Guru memperlihatkan beberapa kalimat yang sempurna, lalu para siswa disuruh menerangkan mana yang berhubungan dengan kaidah yang telah dipelajari. 2) Guru memperlihatkan kalimat-kalimat yang tidak sempurna hanya titik saja, lalu siswa disuruh mengisinya. 3) Guru memberikan kata-kata, lalu siswa disuruh menyusun kalimat sempurna dari kata-kata itu sesuai dengan kaidah yang telah dipelajari. 4) Guru menyuruh siswa membuat kalimat-kalimat yag sempurna dari kalangan siswa sendiri sesuai dengan kaidah tersebut. 5) Supaya siswa terangsang hendaklah guru bisa menggabungkan dengan materi lain. ${ }^{20}$

\section{Keterampilan Bahasa Arab}

\section{Keterampilan Mendengar (Maharat al-Istima')}

Istima' merupakan kumpulan fitur bunyi yang terkandung dalam mufrodat. Keterampilan Istima' diarahkan pada keterampilan menyimak dengan tidak melepas konteks. Mendengar merupakan keterampilan pertama yang dilakukan oleh seseorang dalam belajar berbahasa. Menyimak dapat menjadi alat ukur tingkat kesuitan yang dialami oleh seseorang yang belajar bahasa, karena dari

\footnotetext{
${ }^{20}$ Rosyidin,hlm. 69
} 
keterampilan ini maka kita bisa tau pemahaman dialeknya, pola pengucapannys, struktur bahasa dan lain sebagainya. ${ }^{21}$

Langkah pembelajaran keterampilan istima':1) Strategi pengenalan bunyibunyi bahasa Arab secara tepat. 2) Strategi mendengarkan dan menirukan. 3) Strategi latihan mendengarkan dan memahami.

\section{Keterampilan berbicara (Maharah al-Kalam)}

Berbicara adalah kemampuan mengucapkan bunyi-bunyi artikulasi dan kata-kata untuk mengekspresikan, menyatakan, serta menyampaikan oikiran, gagasan dan perasaan. Dalam arti luas dapat dikatakan bahwa berbicara merupakan suatu sistem tanda-tanda yang dapat di dengar (audible) dan yang kelihatan (visible) yanng memanfaatkan sejumlah otot tubuh manusia demi maksud dan tujuan gagasan-gagasan atau ide-ide yang dikombinasikan. ${ }^{22}$

Langkah Pembelajaran keterampilan berbicara: 1) Belajar kalam yakni berlatih berbicara. 2) Hendaknya siswa mengungkapkantentang pengalaman mereka. 3) Melatih siswa memusatkan perhatian. 4) Hendaknya guru tidak memusatkan percakapan dan sering membenarkan. 5) Bertahap. 6) Kebermaknaan tema, siswaakan lebih termotivasi untuk berbicara jika temanya berhubungan dengan hal yang bernilai dalam kehidupan mereka. ${ }^{23}$

\section{Keterampilan Membaca (Maharat al-Qira'at)}

Membaca (qira'ah) merupakan keterampilan menangkap makna dalam simbol-simbol bunyi tertulis yang terorganisir menurut sistem tertentu atau membaca nyaring bermakna dan memahami berbagai nuansa makna yang dijumpai dalam teks tertulis dengan variasi tujuan komunikasi struktur kalimat dan ciri-ciri bahasanya. ${ }^{24}$

Langkah pembelajaran keterampilan membaca: 1) Mengubah lambang tulis menjadi bunyi. 2) Memperkaya kosa kata. 3) Mengenal pola kalimat. 4) Mengenal (kognisi) isi bacaan. 5) Memahami makna bacaan. 6) Mengevaluasi isi bacaan.

\section{Keterampilan Menulis (Maharat al-Kitabah).}

\footnotetext{
${ }^{21}$ Taufik, Pembelajaran Bahasa Arab MI (Metode Aplikatif \& Inofatif Berbasis ICT), (Surabaya: PMN, 2011), hlm. 45

${ }^{22}$ Djago Taringan dkk, Pengembangan Keterampilan Berbicara, (Jakarta: Departemen Pendidikan dan Kebudayaan, 1997), hlm 6.

${ }^{23}$ Abd Wahab Rosyidi \& Mamlu'atul Ni'mah, Memahami konsep Dasar Pembelajaran Bahasa Arab, (Malang: UIN-Maliki Press, 2011), hlm. 94

${ }^{24}$ Suja'i,Inovasi Pembelajaran Bahasa Arab, (Semarang:Walisongo Press, 2008), hlm. 20
} 
Keterampilan menulis merupakan keterampilan penting dalam pembelajaran bahasa Arab. Dengan menulis seseorang bisa mengaktualisasikan kemampuanna dan spesialisasi kelmuannya kepada publik. ${ }^{25}$

Langkah pembelajaran keterampilan menulis: 1) Mencontoh, 2) Reproduksi, 3) Imlak, 4) Rekombinasi dan Transformasi, 5) Mengarang Terpimpin, 6) Mengarang Bebas. ${ }^{26}$

\section{Kesimpulan}

pembelajaran bahasa arab adalah pembelajaran yang menyeluruh, guru harus bisa mengembangkan kemampuan dalam merancang pembelajaran yang efisien dan efektif, untuk itu salah satu strategi yang bisa dipakai adalah metakognitif, Mengembangkan metakognitif pembelajar berarti membangun fondasi untuk belajar secara aktif. dimana dengan strategi ini para siswa mampu mengenal kemampuan koknitif dirinya sendiri, sehingga proses belajar tidak hanya dilakukan disekolah tetapi siswa juga bisa belajar mandiri di mana saja.

Untuk mendapatkan kesuksesan belajar yang luar biasa, guru harus melatih siswa untuk merancang apa yang hendak dipelajari, memantau kemajuan belajar siswa, dan menilai apa yang telah dipelajari.

Ketika siswa mampu merancang, memantau, dan merefleksikan proses belajar mereka secara sadar, pada hakikatnya, mereka akan menjadi lebih percaya diri dan lebih mandiri dalam belajar. Kemandirian belajar merupakan sebuah kepemilikan pribadi bagi siswa untuk meneruskan perjalanan panjang mereka dalam memenuhi kebutuhan intelektual dan menemukan dunia informasi tak terbatas. Sedangkan tugas guru disini hanya sebagai demostrator, organisator, motivator, pengarah, dan transmitter saja, siswalah yang berperan aktif dalam proses pembelajaran.

\section{Daftar Pustaka}

Al-Ghulayaini, Mustafa. Tarjamah Jami'ud Durusil Arabiyyah. Semarang: CV AsySyifa, 1991.

\footnotetext{
${ }^{25}$ Taufik, hlm. 59

${ }^{26}$ Ahmad Fuad Effendy, hlm. 143 
Al-Syâfi'I, Muhammad Idris. al-Risâlah, Mustafâ al-Bâby al-Halaby. 1940.

Effendy, Ahmad Fuad. Metodologi Pengajaran Bahasa Arab, Malang: Misykat. 2012.

E Kemp, Jerold. Proses Perancangan Pengajaran. Bandung : ITB, 1994

Frosenborg, Cohors dan Kaune. "Modelling Classroom Discussion and Categirizing Discursive and Metacognitive Activities". In proceeding of CERME 5.

Lee, M dan Baylor AL. Designing Metacognitive maps for Web-Based Learning educational Technology \& society. Volume 9 Nomor 1.

Mudjiman Haris. Belajar Mandiri. Surakarta : UNS Press, 2008.

Munawwir, Ahmad Warson. Al-Munawwir Kamus Bahasa Arab-Indonesia. Surabaya: Pustaka Progresif, 1997.

Peraturan Mentri Agama Republik Indonesia Nomor 000912 Tahun 2013 Tentang Kurikulim Madrasah 2013 Mata Pelajaran Pendidikan Agama Islamdan Bahasa Arab.

Rosyidi, Abdul Wahab. Ilmu al-Ashwat an-Nuthqi. Malang: UIN Malang Press.

Rosyidi, Abd Wahab \& Mamlu'atul Ni'mah. Memahami konsep Dasar Pembelajaran Bahasa Arab. Malang: UIN-Maliki Press, 2011.

Sardiman. Interaksi dan Motivasi Belajar Mandiri. Jakarta: Rajawali, 1990.

Slameto. Belajar dan Faktor yang Mempengaruhinya. Jakarta: Rineka Cipta, 2010.

Suja'i. Inovasi Pembelajaran Bahasa Arab. Semarang:Walisongo Press, 2008.

Taringan, Djago dkk. Pengembangan Keterampilan Berbicara. Jakarta: Departemen Pendidikan dan Kebudayaan, 1997.

Taufik. Pembelajaran Bahasa Arab MI (Metode Aplikatif \& Inofatif Berbasis ICT). Surabaya : PMN, 2011.

Taufik. Pembelajaran Bahasa Arab MI (Metode Aplikatif \& Inofatif Berbasis ICT). Surabaya: PMN, 2011.

Usman, Moh, Uzer. Menjadi Guru Profesional, Bandung: Remaja Rosdakarya, 2006.

Zulhannan. Teknik Pembelajaran Bahasa Arab Interaktif. Jakarta: Rajawali Press, 2014. 